\title{
UNIVERSIDADE, CIDADE E LIBERDADE NO SÉCULO XIII: UMA PERSPECTIVA DE ANÁLISE NA HISTÓRIA DA EDUCAÇÃO
}

\author{
Terezinha Oliveira*
}

Recebido: 11 ago. 2011

Aprovado: 19 set. 2012

* Doutora em História pela Universidade Estadual Paulista Júlio de Mesquita Filho (UNESP). Estágio de Pós-Doutorado em História e Filosofia da Educação na Faculdade de Educação da Universidade de São Paulo (FEUSP). Professora associada do Departamento de Fundamentos da Educação e do Programa de Pós-Graduação em Educação da Universidade Estadual de Maringá. Coordena o Grupo de Pesquisa Transformações Sociais e Educação na Antiguidade e Medievalidade. Bolsista de Produtividade do CNPq (PQII). Maringá, PR, Brasil. E-mail: teleoliv@gmail.com.

Resumo: Nosso objetivo é refletir sobre a relevância da História e da História da Educação na construção do sentimento e do ideal de liberdade. Urdiremos os fios que construirão o texto recuperando documentos medievais do século XIII. Trata-se de duas Cartas sobre a Universidade de Paris e uma referente à libertação de uma Comuna. Retomaremos, também, textos de Tomás de Aquino, pois em consonância com as questões de seu tempo debateu sobre a importância do desenvolvimento intelectivo para a vida em comunidade. A história evidencia que a liberdade não se conquista somente por meio das instituições, pois ainda que o homem viva sob a égide de instituições democráticas, só terá, de fato, liberdade quando detiver o conhecimento necessário para nortear suas ações, em vista de seus interesses particulares e em consonância com os interesses públicos. Por fim, observamos que nosso caminhar teórico segue a linha da história social, uma vez que nela encontramos a possibilidade de aliar a história, a memória e o filosofar para construir um conhecimento no qual o todo do ser humano - o material e o mental - é conservado.

Palavras-chave: História da educação medieval. Universidade. Liberdade.

\section{UNIVERSITY, CITY AND FREEDOM IN THE XIII CENTURY: A PERSPECTIVE OF ANALYSIS IN THE HISTORY OF EDUCATION}

Abstract: Our goal is to reflect on the relevance of History and the History of Education in building the feeling and the ideal of freedom. We will string the words that build the text together recovering the medieval documents of the thirteenth century. At stake are two letters on the University of Paris and one on the release of a Commune. We will also return to Thomas Aquinas's texts, as in accordance with the issues of his time debated on the importance of developing the intellect to community life. History shows that freedom is not achieved only through the institutions, because even though the man lives under the aegis of democratic institutions, he will only have freedom when he holds the necessary knowledge to guide his actions in view of his private interests and also according to public interests. Finally, we note that our theoretical walk follows the social history, since we find in it the possibility of joining history, memory and the philosophy to create a knowledge in which the whole of the human being - the material and the mental - is maintained.

Key words: History of medieval education. University. Freedom.

A liberdade é um tema recorrente desde os tempos mais remotos. Acreditamos, inclusive, que ela e o tema da infinitude ou finitude do universo estão presentes nos debates desde que se tenha alguma forma de registro histórico 
por meio de imagens, monumentos ou escritos. Os homens lutam por ela, conquistam-na ou a perdem de formas distintas. Muitas vezes, perdem-na lutando por ela. É o que nos mostra a história. Segundo Etienne de La Boétie (2009, p. 48), no "Discurso da Servidão Voluntária", "O homem é naturalmente livre e quer sê-lo, mas se amolda facilmente à educação que recebe". Do ponto de vista do autor, os hábitos provenientes da educação formam os homens e esta os torna covardes ou corajosos. Em virtude disso ele propõe que os homens aprendam sempre a lutar pela liberdade e a não se sujeitar à tirania, pois esta retira dele a liberdade.

Estes [homens], dotados de entendimento claro e espírito clarividente, não se contentam, com o populacho, em ver o que está a seus pés sem olhar nem para trás nem para a frente. Lembram-se das coisas do passado para julgar o presente e prever o futuro. São estes que, tendo por si mesmos a cabeça benfeita, ainda a cultivaram com o estudo e o saber. Estes, ainda que a liberdade estivesse inteiramente perdida e banida deste mundo, pensam nela, sentem-na em seu espírito e a saboreiam. E a servidão lhes repugna, por mais que a enfeitem (LA BOÉTIE, 2009, p. 48-49).

Iniciamos nosso texto com as observações de La Boétie porque concordamos com elas e consideramos que a educação na história e a história da educação precisam ser concebidas como instrumentos que conduzem os homens à liberdade. Nesse sentido, o conhecimento, particularmente do passado, deve propiciar às pessoas a oportunidade de lutar e acreditar na liberdade. Por seu turno, deve ser também um impeditivo para a subordinação e para a tirania. O nosso tempo presente nos instiga a refletir sobre a liberdade e o sentimento que a nossa época inspira de liberdade. $\mathrm{O}$ entendimento que temos da liberdade deve espelhar nossa educação/formação ${ }^{1}$.

É por acreditarmos que a história se constitui em uma grande mestra e nos ensina a trilhar caminhos que podem nos conduzir à liberdade que elegemos, neste texto, para tratar da relação entre educação e liberdade, um lócus, um tempo e uma instituição específica da Idade Média: a cidade, o século XIII e a Universidade de Paris.

Sob este aspecto salientamos que as formas como os homens da Idade Média se relacionavam e pensavam suas questões não devem ser vistas como uma

1 Evidentemente não estamos nos referindo somente ao ensino. Nossa compreensão, como historiadores da Educação, ultrapassa os limites dos espaços escolares e universitários e a torna um processo social a ser absorvido nas diferentes instâncias da sociedade. Todavia, vemos na educação formal um caminho necessário à formação, pois nela, em tese, a pessoa absorve os conhecimentos cientificamente produzidos na história. 
experiência isolada do processo histórico mais geral. Ao contrário, precisam ser consideradas como experiências humanas sobre as quais os homens da atualidade podem refletir e, com isso, ensinar e aprender.

A constituição das cidades e, com elas, o surgimento de novos segmentos sociais, fez da ambiência citadina o palco de novos conflitos e novos problemas que os homens tiveram que dar conta. A necessidade de construir um espaço público que proporcionasse o bem comum a todos para poder viver melhor foi um dos momentos mais marcantes no estabelecimento dessas novas exigências. O reconhecimento do direito do outro, a tolerância, entre outras exigências, foram questões abordadas pelos autores da época.

Além disso, o estabelecimento de regras de conduta e de punições para aqueles que as transgredissem aparece tanto nas cartas dadas pelos reis às cidades para que elas pudessem ser administradas, como nas cartas concernentes à Universidade de Paris. Assim, como podemos verificar, trata-se de uma experiência a partir da qual podemos pensar os nossos próprios problemas como, por exemplo, ausência de liberdade, de tolerância, violência no trânsito, direitos do cidadão, dentre outras questões.

Evidentemente, não se trata de transpor a experiência de uma época para outra. Cada época é singular e, por conseguinte, não podemos tratar como receita a experiência de outro tempo. No período medieval, a pena de banimento, por exemplo, era um castigo grave. Banido de uma comuna, o indivíduo tinha dificuldades para ser aceito em outra. Mas, se não podemos transpor ou imitar experiências passadas, podemos, por meio da reflexão e do estudo, buscar formas para resolvermos nossos próprios problemas e constatarmos que, sem o estabelecimento de regras e sem a sua obediência, uma comunidade dificilmente consegue resolver muitos de seus problemas.

É, pois, com este objetivo, ou seja, de tomar dos homens citadinos medievais alguns parâmetros sociais que nos possibilitem buscar soluções para problemas sociais de nossa época, especialmente na ambiência da Educação e no entendimento do que seja liberdade, que propomos analisar duas Cartas relativas à Universidade de Paris - "Sentença oficial da cúria de Paris contra os clérigos e alunos que, de dia e de noite, invadem Paris com armas e cometem escândalos" e "Simão cardeal legado estabelece que o reitor seja eleito quatro vezes ao ano; prescreve, acima de tudo, a norma da eleição" -, uma Carta que trata da liberdade de Comuna - "Concessão do conde e da condessa de Flandre de uma nova constituição échevinale, setembro de 1228" - e escritos de Tomás de Aquino que apontam para a importância do desenvolvimento do intelecto para que o homem tenha discernimento sobre seus atos. Estes documentos e 
textos do mestre Tomás serão analisados considerando a estreita relação existente entre a cidade e a universidade. Nosso ponto de partida é explicitar que a universidade como lócus do saber só poderia surgir na cidade e em decorrência das condições sociais criadas nessa ambiência.

A universidade medieval só pôde existir no lócus da cidade, ou seja, essa instituição surge exatamente por que também fora criado o espaço citadino. Em última instância, fora criado o espaço do público, do circulante, do diverso, do confuso, do mercado, que é a urbis medieva. É, pois, nesta instituição e neste espaço especificamente urbano e universal ${ }^{2}$ que verificamos a presença dos mestres e, especialmente, dos mestres mendicantes. Neste sentido, as corporações de ofício e as corporações universitárias expressam o todo que seriam a cidade e as novas relações sociais.

Além dessas características, existe outro motivo não menos importante a ser considerado no que diz respeito às cidades medievais e às universidades como centros de saberes importantes a serem investigados pelo historiador da educação. Trata-se da maneira como concebemos os homens e, por conseguinte, suas relações sociais. Do nosso ponto de vista, este estudo permite que compreendamos um pouco mais como construímos nosso conhecimento, nossas instituições, nossa legislação e nossas identidades. O conhecimento da história constitui condição primordial para se compreender que as verdades do passado eram, de fato, verdades para aqueles homens que nelas acreditavam, independentemente do que possamos hoje pensar a respeito delas. A 'aceitação do passado' é um passo decisivo para se construir o conhecimento do presente.

As sábias palavras de Tomás de Aquino, citadas por Grabmann, indicam em que medida os autores e os acontecimentos do passado são fundamentais para a compreensão de nossas verdades do presente.

Na procura da verdade, de dois modos somos ajudados pelos demais. [...] Quando todos os pensadores anteriores encontraram um aspecto da verdade, tais achados ficam sintetizados na sua unidade e totalidade para os investigadores posteriores, como poderoso recurso para um conhecimento integral da verdade. Indiretamente os pensadores seguintes são ajudados pelos anteriores, nisso que os erros dos primeiros dão aos últimos ensejo para esclarecer a verdade num sério trabalho intelectual. Eqüitativo é, por conseguinte, sejamos agradecidos a todos aqueles que nos hão ajudado no esforço pelo bem da

$2 \mathrm{O}$ conceito de universal vincula-se ao fato de que nas universidades medievais, especialmente a parisiense, assiste-se a circulação de pessoas de diferentes regiões do Ocidente que se agrupam como 'nações', e este é um fenômeno novo no cenário do medievo ocidental. 
verdade". Esta concepção, de ressaibo aristotélico, mostra a estima de Tomás para com os representantes das ciências profanas, tanto na antiguidade como na filosofia árabe e judaica, e a utilização dos seus resultados para a investigação da verdade. O conhecimento da história da filosofia não é para ele um fim em si mesmo, mas apenas o mantém no conhecimento da verdade: "O estudo da filosofia não tem por fim saber o que os outros pensaram senão conhecer como é a verdade das coisas" (GRABMANN, 1946, p. 113-114).

Nos textos do mestre Tomás, os autores do passado são tratados como aqueles que fundaram o alicerce de conhecimentos que possibilitam, aos homens do presente (no caso de Tomás de Aquino, o século XIII; no nosso, o século $\mathrm{XXI}$ ), igualmente construírem suas verdades e suas raízes. Da passagem acima, podemos destacar a necessidade de se conhecer os autores do passado não para pensarmos como eles ou reproduzirmos suas experiências, mas para sabermos como os homens produziram seus saberes e suas relações, que o mestre Tomás chama de verdade ${ }^{3}$. Muitos autores, anteriores ao mestre Tomás já haviam alertado para a importância de se conhecer a história. Hugo de Saint-Victor, um século antes do mestre dominicano, destacou que:

Sem dúvida é mister, no estudo, que você aprenda, antes de tudo, a história e a verdade dos fatos, retomando do começo ao fim: 1) o que foi feito, 2) quando foi feito, 3) onde foi feito, 4) por quais pessoas foi feito. Na história devem ser procurados, sobretudo, estes quatro dados: a pessoas, o fato, o tempo e o lugar. Eu não posso considerar que você tornou-se perfeitamente sutil na alegoria, se antes não estiver consolidado na história. Não queira desprezar estes detalhes. Aquele que despreza as coisas mínimas aos poucos definha. Se você tivesse desdenhado de aprender como primeira coisa o alfabeto, agora não teria o nome nem entre os estudiosos de gramática. Sei que há alguns que querem logo fazer teorias filosóficas. Dizem que as fábulas devem ser deixadas com os pseudo-apóstolos. O saber deles é parecido com a figura de um burro. Não imite este tipo de gente: "Imbuído de pequenas coisas tentarás, firme, grandes feitos" (SAINT-VICTOR, 2001, p. 235-237).

3 O sentido ou conceito de Verdade é extremamente importante na concepção tomasiana haja vista o autor apresentar todo um pensamento explicitado nas questões Quolibetais sobre a Verdade. Todavia, o que é importante destacar ao leitor, neste texto, é o entendimento do mestre Tomás no século XIII. Para ele, existem duas naturezas de Verdade: as verdades eternas produzidas pela luz divina e as verdades humanas realizadas por meio do agir humano, portanto, acidentais e mutáveis. É importante destacar isso posto que embora a palavra permaneça a mesma, o seu sentido é bem outro. Para nós, hoje, verdade pode significar a ideia de dogma, para Tomás de Aquino, é a ação humana cotidiana. 
O conhecimento da história é condição, de acordo com os dois autores, para que possamos saber quem somos, como fomos produzidos e como as instituições foram criadas. As palavras de Saint-Victor e de Tomás de Aquino são fundamentais a esse respeito, na medida em que elas explicitam que precisamos conhecer os autores do passado, o período em que escreveram e com quem dialogavam para que possamos tirar lições da história. Além disso, ressalte-se o fato de ambos apresentarem a história sob dois aspectos que precisam ser considerados nos dias atuais. Em primeiro lugar, precisamos conhecer cada uma das partes de um acontecimento. Em segundo lugar, essas partes singulares ou particulares somente ganham sentido se entendidas em sua totalidade, ou seja, se formarem um todo. Aceitemos, então, a sugestão do mestre Vitorino de que somente aprendemos a ler e a escrever após aprendermos o alfabeto; só entendemos a história quando compreendemos o seu caminhar, sempre composto de partes constitutivas do todo.

Aproximemo-nos, portanto, desta concepção de história dos dois mestres medievais mencionados acima, considerando a ideia de liberdade dos homens citadinos e a existência de um princípio de luta em defesa de uma comunidade, onde se construiria o conceito de bem comum. Ao construírem uma ambiência comum, com suas fortalezas, com seus dirigentes próprios, ao conquistarem as cartas de franquias, os habitantes da cidade/comuna/burgo, cada vez mais criavam entre si um sentimento de pertencimento. A liberdade era uma decorrência destas conquistas. Assim, a vida na cidade produziu dois novos sentimentos nos homens: o de pertencimento e o de liberdade. Destaque-se, no entanto, que os dois sentimentos não possuíam características universalizantes como o que se verificava com o cristianismo e com os direitos feudais.

Para os habitantes dos burgos, os interesses comuns eram os da sua comunidade. Não se referia a todos os homens, independentemente do lócus e da situação. Ao contrário, o 'comum' referia-se aos habitantes de uma mesma cidade e o 'bem', também de todos, referia-se apenas aos membros desta mesma comunidade. Os burgueses dos séculos XIII, do mesmo modo que as nações estudantis, como as que participavam da Universidade de Paris, entendiam o bem comum como algo destinado ao seu Grupo. O mestre Tomás exemplificou esse princípio ao afirmar que cada coisa dirige-se ao seu propósito próprio.

Uma coisa dirige-se retamente, quando vai para o fim conveniente; não retamente, porém quando vai para o fim não conveniente. Um, porém, é o fim conveniente à multidão dos livres, e outro à dos escravos; visto como o livre é a sua própria causa, ao passo que o 
escravo, no que é pertence a outrem. Se, pois, a multidão dos livres é ordenada pelo governante ao bem comum da multidão, o regime será reto e justo, como aos livres convém (TOMÁS DE AQUINO, 1997, L. I, c. II).

Nesse sentido, quando os burgueses, os estudantes e o mestre Tomás defendiam e buscavam o bem comum, este estava vinculado ao Grupo a que pertenciam. A passagem do mestre Dominicano é explícita: a cidade é a comunidade perfeita para os homens livres. Aliás, considerando o cenário medieval, era nas cidades que os homens comuns conseguiam a liberdade. Assim, o conceito de bem comum em Tomás de Aquino e para os habitantes dos burgos não dizia respeito ao universo de todos os homens que compunham a sociedade medieval, mas restringia-se aos citadinos.

Nesse sentido, não houve na Idade Média um conceito de liberdade geral, que não estivesse restrito a determinados condicionantes sociais, do mesmo modo que comunidade e bem comum também se referiam a algo específico. Observamos, sob este aspecto, que foram as relações sociais que deram a estes conceitos suas especificidades e natureza.

Desse modo, quando verificamos as lutas e conquistas dos burgueses dos séculos XIII para obter a liberdade, precisamos considerá-las no universo das relações que estes travavam com os seus senhores. Do mesmo modo que, ao considerarmos as Cartas sobre as Comunas e a Universidade, devemos analisá-las a partir da realidade medieval e do universo de tessituras sociais que compunham as relações de poder entre as cidades, as universidades e os poderes eclesiásticos e laicos. Desse modo, não podemos vê-las como se estivessem completamente submetidas ao poder do papa e dos príncipes, bem como seria um equívoco considerá-las como instituições plenamente livres destes poderes. A universidade, assim como as demais corporações de ofícios dos séculos XIII, vivia e sofria as vicissitudes sociais daquela época. Todavia, por ser uma instituição citadina, a universidade lutava pela liberdade de ensino, pelos seus interesses e pelo bem comum de seus pares, da mesma maneira que os habitantes da comuna.

A luta dos citadinos tinha como fito a liberdade de comercializar sem ter que se submeter ao jugo e aos impostos dos senhores feudais; a liberdade implicava também poder circular de uma cidade para outra sem ser saqueado pelos homens do senhor, por que, não podemos nos esquecer, a cidade fora erigida nas entranhas de um feudo. Por seu turno, os mestres e os alunos da universidade lutavam também pela liberdade de ir e vir e de poder ensinar conteúdos diversos 
daqueles das Escrituras Sagradas, especialmente os escritos aristotélicos. Ambas as corporações, a dos mestres artesãos e a dos mestres universitários, lutavam pela liberdade de circulação das pessoas que as compunham e de seus ofícios e viam como 'natural' o governo político da comuna/cidade estar nas mãos das autoridades laicas ou eclesiásticas. Como os homens citadinos do século XIII viviam e travavam suas relações a partir do universo feudal e de suas leis. Para eles, o poder estava mesmo nas mãos dos senhores; suas lutas, em tese, se restringiam a conquistar a liberdade mencionada. Não consideravam que suas reivindicações atingiriam as bases da sociedade medieva do Ocidente. Fazia parte de suas vidas pedirem proteção aos senhores e legitimar ora o poder do príncipe, ora o poder do papa. Não identificavam nesses poderes seus inimigos, desde que conquistassem a liberdade para suas atividades.

Eis os princípios e a trajetória que nos levam aos documentos a serem analisados. Procuraremos ver como eles expressavam a vida destes homens. São textos que revelam ora o embate entre interesses distintos, ora os benefícios e proteção dos poderes constituídos. A seguir, examinaremos as Cartas. Principiemos pelas que tratam do cotidiano da Universidade de Paris. As Cartas sobre a Universidade que analisaremos são a de $n^{\circ} .426$ e a de $n^{\circ} .492$ - do conjunto de cartas sobre a Universidade de Paris, compiladas por Denifle, em fins do século XIX.

A Carta de n. 426 de 1269, cujo título é "Sentença oficial da cúria de Paris contra os clérigos e alunos que, de dia e de noite, invadem Paris com armas e cometem escândalos".

[...] alguns clérigos e alunos e também os seus serventes, confiando na insanidade dos mesmos clérigos, esquecidos da sua salvação, não tendo Deus diante de si, são parisienses que conduzem a vida escolar [escolástica] planejando muitas vezes atos ilícitos e maléficos e, pior, confiantes no poder das armas perpetram e executam isto, ou seja, de dia e de noite ferem cruelmente a muitos, matam, raptam mulheres, oprimem virgens, destroem abrigos, [...] E porque esses e outros atos são atentados pelo uso e poder das armas, nos, [...] decretamos que os clérigos portadores de armas sejam excomungados; [...] deve-se providenciar que haja paz e tranqüilidade dos estudantes e de outros que querem viver em paz: [...]. Excomungamos também por escrito todos os raptores de mulheres, destruidores de abrigos, opressores das virgens, e também todos aqueles que se coligaram para realizarem isso. [...] alguns clérigos e alunos e os serventes deles, que vindo a Paris de suas regiões ou voltando para suas regiões trouxeram as armas a Paris, e também outros, clérigos, alunos e os serventes deles teriam transportado as armas de Paris, deve-se verificar pelas causas 
preditas se eles incorreriam na predita sentença de excomunhão, por ato continuo dos presentes declaramos que não é nem foi nossa intenção que a citada sentença atinjam aqueles clérigos, alunos e os serventes deles, que, vindo a Paris por causa dos estudos trouxeram as armas habituais pelo caminho, levaram-nas até o abrigo no primeiro ingresso na cidade de Paris, nem também aqueles que queriam repatriar ou por negócios úteis e honestos além da estada diária, partiam da cidade de Paris, indo e voltando transportavam armas semelhantes enquanto saiam da cidade. Declaramos ainda que aquela cláusula pela qual se diz: "excomungamos todos aqueles que souberem algo das premissas (fundamentos)", etc., que não entendemos [que] aquela palavra inicial refira a todas e a cada uma das premissas, mas às cláusulas imediatamente precedentes, ou seja, sobre os raptores de mulheres, destruidores dos abrigos, opressores das virgens e daqueles que se coligaram para realizarem isso [...] (DENIFLE, 1899, Carta 426, v. II, p. 481-482. Trad. Livre).

Esta Carta reflete as relações travadas entre as pessoas da universidade e a comunidade que a envolve. Alguns aspectos dela precisam ser esclarecidos ao leitor. Em primeiro lugar, era muito comum nesse período que os homens da Igreja, especialmente os bispos, editassem regras e leis para o convívio social. Em segundo lugar, destaque-se que nessa época a palavra clérigo designava o intelectual que se dedicava exclusivamente ao estudo e ao ensino, portanto, não estava relacionada à carreira eclesiástica ou aos frades regulares. Feitas essas ressalvas, observamos que o teor da Carta revela a relação pouco amistosa existente entre os universitários e a comunidade local. Pelo teor do documento é visível que se trata de medida punitiva contra os estudantes e os mestres que, segundo a sentença da Cúria, estariam ameaçando a paz e a liberdade das pessoas, inclusive das mulheres. A medida, a princípio, preocupava-se em proteger a população local dos atos de vandalismo e criminosos da comunidade universitária, especialmente no que se refere ao porte de armas. Todavia, se contextualizarmos o documento com outros do período e com a história das universidades no século XIII depreendemos que existia um grande conflito entre os universitários e os poderes locais da Igreja, particularmente os bispos. A própria Carta aponta, na "Sentença", um caráter ambíguo, pois, ao mesmo tempo em que proíbe os universitários a portarem armas, concede este direito a outros universitários que estariam em circulação entre as cidades, entre as regiões, etc., pois em virtude da insegurança que grassava na época, o porte de armas constituía-se em condição de preservação da vida. A Carta revela que as autoridades locais tinham a preocupação em conservar a paz na cidade, mas não tinham muito explícito quais estudantes deveriam ou não ser punidos. 
A segunda Carta da Universidade, a de no. 492 de 1279, intitulada "Simão cardeal legado estabelece que o reitor seja eleito quatro vezes ao ano; prescreve, acima de tudo, a norma da eleição".

Como, observando mais diligentemente que aquele uso, ou melhor, um abuso reprovável e danoso introduzido não de longos tempos atrás, isto é, que o reitor da Universidade de Paris a cada mês ou seis semanas, administrava a perturbação do estudo e ainda o incentivo à inveja, decidimos abolir esse costume, estabelecendo [...] que o reitor seja eleito quatro vezes ao ano, ou seja, no primeiro dia útil depois da festa do beato Dionysio, no último dia útil antes das férias que precedem o Natal, no último dia útil antes da Anunciação da bem-aventurada Virgem Maria, e no último dia útil antes da festa do bem-aventurado João Batista, não mais vezes; que o reitor possa exercer livremente o cargo de reitoria pelo tempo para o qual foi eleito, [...] Acrescentamos ainda a esta ordem [norma] nossa que um único reitor seja eleito por quatro procuradores das nações da Universidade citada [...] que o reitor seja eleito desta forma no futuro, que quatro procuradores das quatro nações citadas juramentado solenemente sobre a sagrada Escritura diante das mesmas nações elegerão com boa fé [confiança] outro diferente do predecessor para reitor da mesma Universidade, [...] aquele que, segundo sua consciência, acreditarem ser o melhor na função de reitor, não movidos por razão de discórdia precedente, não movidos por amor ou temor, ódio ou honra ou pudor de alguma das nações supracitadas, nem movidos por amor ou ódio, honra ou utilidade de alguma pessoa, mas por causa do bem comum de todo o estudo lembrado, e aquele que for aceito pelos quatro assim juramentados ou por três deles, será reitor da Universidade citada até o final do tempo prefixado. [...] (DENIFLE, 1899, v. I, p. 576-577. Trad. Livre).

Esta Carta espelha com nitidez a organização interna da universidade. O primeiro aspecto importante a ser destacado é que o reitor era eleito e não poderia gerir a instituição por mais que 120 dias. A decisão de estabelecer um período foi tomada para evitar abusos na administração, pois, antes, pelo fato de o reitor dirigir pelo curto período de um mês ou seis semanas, fazia com que não tivesse suficiente controle sobre a universidade. Portanto, tornara-se necessário prolongar seu período de administração. Cada nação presente na Casa indicava um representante (o espaço da universidade era designada como casa) para eleger o reitor. Vale destacar que as quatro nações mencionadas na Carta designam as quatro regiões (do que viria ser a Europa) de onde provinham os alunos da Universidade de Paris. São os mestres e alunos, portanto, que elegem o reitor. Observa-se, na Carta, que o reitor, independente de que nação 
fosse, deveria zelar para que a paz prevalecesse e que os interesses comuns, da universidade, sempre se sobrepusessem aos interesses particulares de cada nação. As quatro eleições que ocorriam para reitor, ao longo do ano, já tinham sua data definida a priori e coincidiam com datas consagradas pela Igreja. É preciso considerar que este fato, em si, não indica ingerência completa desta instituição religiosa sobre a universidade, mas ocorria porque o calendário, na Idade Média, era definido pelas quatro estações do ano que, por sua vez, vinculava-se aos festejos religiosos.

Nesse sentido, a análise deste documento permite-nos não só compreender um pouco da organização da universidade como, fundamentalmente, construir a memória histórica dessa importante instituição de ensino que o medievo nos legou.

A terceira Carta que examinaremos faz parte das Instituições Comunais de Douai $(1228,1250,1261)$ e se intitula "Concessão do conde e da condessa de Flandre de uma nova constituição échevinale, setembro de 1228”.

Ferrand, conde de Flandre e de Hainaut e Jeanne, sua esposa, condessa de Flandre e de Hainaut, à todos aqueles que virem essas presentes cartas, saúde. Saibam todos que nós concedemos a nossos caros burgueses e échevins de Douai o direito de ter um échevinage perpetuamente, renovada de 13 meses em 13 meses, desta maneira. Ao fim do $13^{\circ}$ mês, os échevins que saírem da échevinage devem eleger quatro burgueses da cidade de Douai nos primeiros quatro quarteirões. Esses quatro burgueses eleitos, após ter tocado as relíquias, prestarão juramento de escolher, primeiro, os melhores que puderem quatro outros burgueses que prestarão também juramento. Eles jurarão salvaguardar o direito da Santa Igreja e o nosso, o direito e a lei da cidade. [...] Os primos coirmãos ou as pessoas ainda mais próximas em parentesco não poderão ser échevins ao mesmo tempo, não mais do que aqueles que um é casado com a filha do outro. Os échevins que foram échevins durante 13 meses não poderão sê-lo de novo durante os 13 meses consecutivos. Nós lhes havíamos concedido, além disso, os usos e costumes e as leis que eles tiveram no tempo do falecido Felipe, conde de Flandre, de boa memória.

$[\ldots]$

Em testemunho das cláusulas sobreditas, nós colocamos nesta presente carta nosso selo. Feita em Quesnoy, no ano do senhor 1228, no mês de setembro (BEAUMANOIR; BEUGNOT, 1842. Trad. Livre).

Trata-se de uma Carta na qual um casal de nobres concede à cidade de Douai (importante cidade têxtil) o direito de ter e eleger um échevin, uma espécie de administrador, representante dos burgueses. Este cargo só existia em cidades ou comunas que já possuíam franquia/liberdade. É importante destacar que só 
poderia ser eleito échevin a pessoa que fosse considerada a melhor dentre os habitantes da comunidade. Aliás, em carta de 1250, por ocasião do juramento de um almotacé, cargo similar ao de échevin, o primeiro item a ser jurado é que a pessoa se comprometia a ser um homem prudente e justo. Outro aspecto que merece ser destacado na Carta é o fato de a pessoa só administrar por 13 meses e não poder ser reeleita em seguida, ou seja, prosseguir sem interrupção o seu cargo. Destaque-se, também, o cuidado de, ao eleger o échevin, não permitir que nenhum parente assumisse qualquer cargo administrativo durante sua gestão, ou seja, os citadinos do século XIII zelavam e se precaviam contra o nepotismo. Por fim, o último aspecto importante a ser salientado na Carta diz respeito ao fato de ela ser promulgada pelos senhores feudais da cidade e isso não significar problema para os habitantes dos burgos. Isto ilustra a ideia que já mencionamos em outro momento de nosso texto: as reivindicações dos citadinos das comunas não eram para destruir o poder dos senhores, mas, sim, para poderem viver em liberdade e exercerem, livremente, suas atividades nas cidades.

O exemplo dessa Carta, mais uma vez, evidencia a importância desses documentos para se entender nossas origens históricas e recuperar a memória de nossas origens ou, dito de outro modo, as origens da sociedade burguesa. Por fim, revela-nos algo essencial: as palavras permanecem na história, no tempo, mas o seu significado se modifica na medida em que as relações sociais se transformam. Hoje, para nós, é difícil entender o conceito de liberdade dos burgueses do século XIII, pois, para nós, liberdade está vinculada a independência, ao ir e vir. Todavia, para os citadinos, liberdade era o direito de eleger seus administradores, ainda que sob a chancela do senhor, para que eles fizessem valer o direito à liberdade de comercializar e de se deslocar.

Após refletirmos estes três documentos que revelam a organização da vida dos homens citadinos e universitários e desvelam caminhos que apontam para a conquista da liberdade, passaremos a considerar como estas relações foram tratadas por um mestre da universidade que conviveu e ensinou no cenário parisiense, Tomás de Aquino.

Um dos aspectos mais originais, para o século XIII, da análise tomasiana do intelecto diz respeito à forma como o mestre trata o próprio ser humano. A refletir na "Suma Teológica", Ia, questão 3, a. 1 se 'Seria Deus um corpo?', o mestre observa uma das questões mais cruciais da existência humana: o homem possui corpo porque sua existência tem uma finalidade, ou seja, o corpo sem o intelecto que direciona o seu agir não é um ser humano porque ele não age com a razão, mas com os sentidos sensitivos, tal como os animais. Diferente- 
mente de Deus, que age independente do corpo e é um ser perfeito que existe sem materialidade, o homem vive a partir de sua materialidade corpórea e intelectual/alma:

$[\ldots]$ o corpo vivo não vive por ser corpo, $[. .$.$] ; é preciso que viva por$ alguma outra coisa, como nosso corpo vive pela alma. Ora o que leva o corpo a viver é mais nobre do que ele. Por conseguinte, é impossível Deus ser um corpo" (TOMÁS DE AQUINO, 2001-2006, I, q. 3, a. 1).

Ao contrário de Deus, que é o ser perfeito e supremo, que não precisa da matéria para ser/existir, os homens, por serem imperfeitos, somente se realizam a partir do seu duplo aspecto: corpóreo e intelectivo. Para o mestre, o corpo não é somente o depositário do intelecto, mas é parte do ser pessoa; sem ele o homem não existiria. O intelecto é a parte fundamental do homem porque é ele que comanda suas ações cotidianas. O intelecto se constitui, pois, para Tomás de Aquino, no agente humano.

É o intelecto que possibilita ao homem ter atitudes que o aproximam da perfeição, existente somente no bem supremo. Ou seja, ele é a parte que permite que o homem conheça todas as coisas, que defina seus caminhos e que chegue, inclusive, a Deus. Nesse sentido, o homem não é bom ou mal porque é homem, assim como o fato de ser homem não o faz, naturalmente, ser semelhante a Deus. Mas são os seus atos, comandados pelo intelecto, que faz o homem se aproximar ou não da perfeição divina. Assim, o que distingue o homem dos demais animais é seu agir, proveniente de suas decisões intelectuais. Exatamente por isso o intelecto humano não pode ser único para todos os homens, pois isso retiraria do homem seus atos particulares e seu agir independeria de sua vontade.

O mestre dominicano atribui à natureza intelectual do homem uma vontade própria, responsável para e pelos seus atos. Do seu pensamento depreende-se que os homens possuem, particularmente, vontade e liberdade para realizar suas ações de um modo ou outro.

Se alguém disser que um homem concreto é o próprio intelecto, seguir-se-á que este homem em concreto não se distingue daquele homem em concreto e que todos os homens são um só homem, não, é claro, pela participação na espécie, mas segundo um único indivíduo. Todavia, se o intelecto se encontrar em nós formalmente, tal como já dissemos, segue-se que as almas são diversas conforme os diversos corpos. Tal como o homem consta de um corpo e de uma alma, assim também este homem, seja Cális ou Sócrates, consta deste corpo e desta alma. Mas se as almas são diversas e se o intelecto possível é 
a faculdade da alma pela qual a alma pensa, então é necessário que ele seja diferente em número, pois nem sequer é possível imaginar que haja uma faculdade numericamente única para coisas diversas (TOMÁS DE AQUINO, 1999, c. IV, § 84-85).

Ao afirmar que 'intelecto possível é aquilo pelo qual pensamos', Tomás de Aquino atribui aos homens uma autoridade e uma liberdade que não se tinha admitido até então no medievo. Como cada sujeito possui corpo e intelecto próprio, depende unicamente dele os rumos que dá à sua vida, pois, na medida em que a alma é diversa e é pela alma que o homem pensa, não pode haver 'numericamente' um único modo de agir e pensar. Se isso fosse possível, os homens seriam unicamente bons ou maus, o que, sabidamente, não é verdadeiro. Por possuir esse entendimento do que seja o homem, o mestre afiança que cada homem pensa por si. Com efeito, o 'homem é homem porque pensa' e esse pensar, que o diferencia não apenas dos demais animais, mas dos demais da sua espécie, faz com que ele, homem, seja sujeito singular pelo seu pensar e agir.

[...] ora a operação própria do homem, enquanto é homem, consiste em pensar, pois nisto que difere dos outros animais, e por isso é que Aristóteles deposita a última felicidade nessa operação. O princípio pelo qual pensamos é o intelecto, tal como Aristóteles diz. Deve, portanto, unir-se ao corpo como uma forma, não de maneira a que a própria potência intelectiva seja o acto de algum órgão, mas por ser uma faculdade da alma que é o acto de um corpo natural organizado (TOMÁS DE AQUINO, 1999, c. III, § 75 e 77. Grifo nosso).

Desse modo, somente o homem é responsável pelos seus atos. Assim, embora os homens pertençam à mesma espécie e sejam iguais entre si, em termos corpóreos, eles se diferenciam uns dos outros pelo seu pensar. Essa é, indubitavelmente, a grande revolução teórica promovida pelo mestre dominicano. Para o mestre, as atividades humanas existiam e os homens podiam ensinar e aprender exatamente porque pensavam e faziam uso do pensar para tornar suas habilidades, que existiam enquanto potência, em ato. Era a capacidade do pensar que permitia a capacidade cognitiva do homem dirigir sua ação para coisas justas ou injustas. Era esta possibilidade intelectiva que conduzia os homens à prudência, que possibilitava a existência de governos justos e equitativos, por conseguinte, a conquista da liberdade. Para o mestre Tomás, 'o intelecto humano era o grande motor da existência dos homens'. Essa revolução no pensar e essa autonomia intelectiva do homem, apresentada pelo mestre Tomás só foi possível no espaço citadino do século XIII. 


\section{CONSIDERAÇÕES FINAIS}

Para concluirmos nossas reflexões sobre a luta pela liberdade da pessoa e do conhecimento no século XIII, retomemos a ideia posta por La Boétie de que o desejo de liberdade no homem é natural como em todos os demais animais. Contudo, o homem só luta pela liberdade quando 'conhece' e é 'corajoso'. Exatamente por isso, o autor cita como exemplo o personagem Ulisses, de Homero. Aprendemos com os homens citadinos e universitários que a grande mudança ocorrida nesse século não resultou somente do renascimento do comércio, da criação das corporações de ofícios, dentre elas a própria universidade, mas da dupla liberdade que os homens medievais do Ocidente conquistaram. De um lado, uma conquista institucional, uma vez que as cidades obtiveram a liberdade em relação aos seus senhores feudais e puderam, em virtude dessa conquista, organizar um sistema administrativo novo, imbuído do espírito burguês. De outro lado, a autonomia e a liberdade do intelecto, provenientes dos debates teóricos travados e das ideias ensinadas na universidade. Desse modo, pensar o século XIII, o seu ambiente citadino e universitário é muito pertinente na atualidade, pois isso nos mostra e nos ensina que as conquistas sociais, especialmente a liberdade, são realizadas quando as instituições e os indivíduos se desenvolvem em comum e num mesmo compasso. Nesse sentido, espírito e matéria formam um todo, como afiançara o mestre Tomás de Aquino. Quando o espírito ou corpo se desenvolvem separadamente, não existe o ser pessoa. Ou seja, o homem que tem clareza da importância de cuidar dos seus interesses particulares, por ter consciência que vive coletivamente, não descura das ações que se vinculam ao bem comum da sociedade. Ainda, preocupam-se na mesma medida com o desenvolvimento do intelecto e da aparência física. Sob este aspecto a pessoa, identificada pelo mestre Tomás como um ser na totalidade, é tão importante ao século XIII como para os nossos dias. Atualmente, a consciência de que a liberdade é necessária para nos tornarmos homens, no sentido da totalidade, só é alcançada quando conhecemos a história, quando temos clareza que as mazelas ou conquistas do tempo presente não são naturais, mas provenientes de nossas ações e somente delas.

\section{REFERÊNCIAS}

BEAUMANOIR, P. de R.; BEUGNOT, A. A. Les Coutumes du Beauvoisis (S. XIII). Paris: Jules Renouard et $C^{\text {a }}$., 1842. Édition, publiée d'après les manuscrits de la Bibliothéque Royale par le comte Beugnot. 
DENIFLE, H. Chartularium universitas parisiensis. Bruxelles: Culture et Civilisation, 1899. 2 v.

GRABMANN, M. A filosofia da cultura em Tomás de Aquino. Petrópolis: Vozes, 1946.

LA BOÉTIE, E. Discurso da servidão voluntária. São Paulo: Martin Claret, 2009.

SAINT-VICTOR, HUGO de. Didascalicon. Da arte de ler. Petrópolis: Vozes, 2001.

TOMÁS DE AQUINO. A Unidade do intelecto. Contra os Averroistas. Lisboa: Edições 70, 1999.

TOMÁS DE AQUINO. Do reino e do governo de Chipre. In: Escritos políticos. Petrópolis: Vozes, 1997.

TOMÁS DE AQUINO. Suma teológica. São Paulo: Paulus, 2001-2006. 